\title{
Pyrolysis Treatment of Chromite Ore Processing Residue by Biomass: Cellulose Pyrolysis and $\mathrm{Cr}(\mathrm{VI})$ Reduction Behavior
}

\author{
Da-Lei Zhang, ${ }^{*}{ }^{\dagger}$ Mei-Yi Zhang, ${ }^{\ddagger}$ Chu-Hui Zhang, ${ }^{\dagger}$ Ying-Jie Sun, ${ }^{\dagger}$ Xiao Sun, ${ }^{\dagger}$ and Xian-Zheng Yuan ${ }^{*} \S$ \\ ${ }^{\dagger}$ School of Environmental and Municipal Engineering, Qingdao Technological University, Qingdao, Shandong Province 266033 P. R. \\ China \\ ${ }^{\ddagger}$ Research Center for Eco-Environmental Sciences, Chinese Academy of Sciences, Beijing, 100085, P. R. China \\ ${ }^{\S}$ Key Laboratory of Biofuels, Qingdao Institute of Bioenergy and Bioprocess Technology, Chinese Academy of Sciences, Qingdao, \\ Shandong Province 266101, P. R. China
}

\section{Supporting Information}

ABSTRACT: The pyrolysis treatment with biomass is a promising technology for the remediation of chromite-oreprocessing residue (COPR). However, the mechanism of this process is still unclear. In this study, the behavior of pyrolysis reduction of $\mathrm{Cr}(\mathrm{VI})$ by cellulose, the main component of biomass, was elucidated. The results showed that the volatile fraction (VF) of cellulose, ie. gas and tar, was responsible for $\mathrm{Cr}(\mathrm{VI})$ reduction. All organic compounds, as well as $\mathrm{CO}$ and $\mathrm{H}_{2}$ in VF, potentially reduced $\mathrm{Cr}(\mathrm{VI})$. X-ray absorption nearedge structure (XANES) spectroscopy and extended X-ray absorption fine-structure (EXAFS) spectroscopy confirmed the reduction of $\mathrm{Cr}(\mathrm{VI})$ to $\mathrm{Cr}(\mathrm{III})$ and the formation of amorphous $\mathrm{Cr}_{2} \mathrm{O}_{3}$. The remnant $\mathrm{Cr}(\mathrm{VI})$ content in COPR can

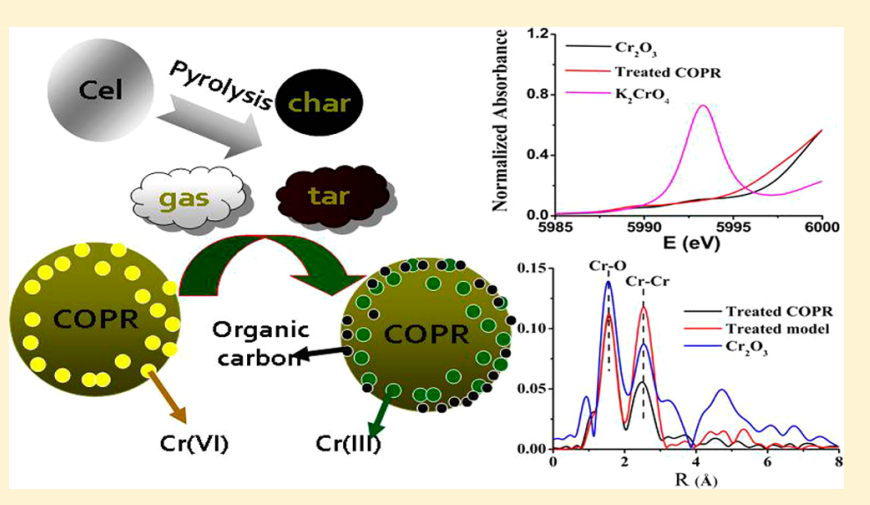
be reduced below the detection limit $(2 \mathrm{mg} / \mathrm{kg})$ by the reduction of COPR particle and extension of reaction time between VF and COPR. This study provided a deep insight on the co-pyrolysis of cellulose with $\mathrm{Cr}(\mathrm{VI})$ in COPR and an ideal approach by which to characterize and optimize the pyrolysis treatment for COPR by other organics.

\section{INTRODUCTION}

Chromite-ore-processing residue (COPR) is a byproduct of the chromite-ore high-temperature lime-based roasting process to isolate and extract $\mathrm{Cr}(\mathrm{VI})$. In this process, chromite ore is roasted at $1200{ }^{\circ} \mathrm{C}$, oxidizing $\mathrm{Cr}(\mathrm{III})$ to $\mathrm{Cr}(\mathrm{VI})$, and then the $\mathrm{Cr}(\mathrm{VI})$ chemically combines with the soda ash to form sodium chromate. During the roasting process, lime acts as a mechanical separator, allowing oxygen to react with the chromite and sodium carbonate. ${ }^{1}$ Due to the fact that the COPR contains a large amount of toxic $\mathrm{Cr}(\mathrm{VI})$, nonlime-based process had substituted the lime-based process in the developed countries, such as the United States, U.K. and Germany, etc. ${ }^{2}$ However, lots of abandoned COPR deposit sites need to be remediated. ${ }^{1,3-6}$ In addition, compared to the nonlime process, the lime-based process also has advantages in the chromium recovery efficiency, ${ }^{1}$ especially from chromite ore with high $\mathrm{Al}$ and $\mathrm{Si}$ content. Hence, the lime-based process, which is still used in Russia, China, India, Pakistan, etc., ${ }^{2}$ could not be totally abandoned worldwide and may exist for a long time. As a result, more attention should be paid to the remediation of the COPR.

For the treatment of COPR, reduction of the $\mathrm{Cr}(\mathrm{VI})$ to nontoxic $\mathrm{Cr}(\mathrm{III})$ is generally considered satisfactory. ${ }^{7,8}$ It is practicable that $\mathrm{Cr}(\mathrm{VI})$ was extracted from COPR into aqueous solution and reduced into $\mathrm{Cr}$ (III) by reductants, such as $\mathrm{Fe}$ (II), sulfide, and calcium polysulfide. ${ }^{9,10}$ However, in this process, the ineffective release of $\mathrm{Cr}(\mathrm{VI})$ into the solution from the solid subsequently delays the reduction. ${ }^{11,12}$ In addition, the oxidation of the reductants by air caused the ineffectiveness in $\mathrm{Cr}(\mathrm{VI})$ reduction due to the hyperalkaline condition caused by COPR. ${ }^{13}$ Thus, the process usually requires a long curing time (up to a few months). ${ }^{14}$

In previous research, a new technology for treatment of COPR was investigated. ${ }^{15,16}$ In this process, COPR was initially mixed with rice straw and subsequently pyrolyzed at low temperatures. The $\mathrm{Cr}(\mathrm{VI})$ in COPR could be reduced into $\mathrm{Cr}$ (III) in less than 10 min of reaction time combined with low energy consumption of $43 \mathrm{~kg}$ of standard coal per ton of COPR. ${ }^{16}$ The pilot-scale experiment with $20 \mathrm{t}$ of COPR per day (shown in Note $S 1$ of the Supporting Information) indicated that the treatment cost is less than 30 USD per ton of COPR. In addition, the dry process reduced the volume of the treated material, and the pyrolysis product of the biomass (i.e., the char) is environmentally friendly. The treated COPR could be reused as construction material due to its cementitious characteristics by this process.

Received: November 19, 2015

Accepted: February 10, 2016

Published: February 10, 2016 
Although the process is promising for the remediation of COPR, the mechanism of this process should be further elucidated. The rice straw is a kind of biomass that consists of cellulose, hemicellulose, and lignin. Each component plays a different role in $\mathrm{Cr}(\mathrm{VI})$ reduction during co-pyrolysis with COPR. In the present study, the $\mathrm{Cr}(\mathrm{VI})$ reduction behavior with the co-pyrolysis of cellulose was investigated. The influence of pyrolysis variables, including temperature and reaction time, on the distribution of pyrolysis products of cellulose in terms of char, tar, and gas (as well as $\mathrm{Cr}$ (VI) reduction percentage) was investigated. The interaction between the volatile fraction (VF) of cellulose and $\mathrm{Cr}(\mathrm{VI})$ reduction was elucidated. In addition, X-ray absorption nearedge structure (XANES) spectroscopy and extended X-ray absorption fine-structure (EXAFS) spectroscopy were used to determine Cr speciation.

\section{MATERIALS AND METHODS}

Materials. The COPR was collected from the deposition site of a chromate production plant located in Jinan, Shandong Province, China. The raw materials for chromate production were chromite, dolomite $\left(\mathrm{CaCO}_{3} \cdot \mathrm{MgCO}_{3}\right)$, and $\mathrm{Na}_{2} \mathrm{CO}_{3}$. The sample was sieved to 40 mesh and dried at $105{ }^{\circ} \mathrm{C}$ before used. The contents of total chromium and $\mathrm{Cr}(\mathrm{VI})$ in the sample were $27600 \mathrm{mg} \mathrm{kg}^{-1}$ and $6750 \mathrm{mg} \mathrm{kg}$, respectively, with $\mathrm{CaO}$ (31.3\%), $\mathrm{MgO}$ (25.4\%), $\mathrm{Al}_{2} \mathrm{O}_{3}(6.1 \%), \mathrm{SiO}_{2}(6.3 \%)$, and $\mathrm{Fe}_{2} \mathrm{O}_{3}$ (11.9\%). XRD pattern of COPR (shown in Figure S3) indicated that this COPR consisted largely of calcite $\left(\mathrm{CaCO}_{3}\right)$ and brownmillerite $\left(\mathrm{Ca}_{2} \mathrm{FeAlO}_{5}\right)$ with minor amounts of portlandite $\left[\mathrm{Ca}(\mathrm{OH})_{2}\right]$, magnesiochromite $\left[(\mathrm{Mg}, \mathrm{Fe})(\mathrm{Cr}, \mathrm{Al})_{2} \mathrm{O}_{4}\right]$, hydrogarnet $\left[\mathrm{Ca}_{3} \mathrm{Al}_{2}\left(\mathrm{H}_{4} \mathrm{O}_{4}\right)_{3}\right]$, and periclase $(\mathrm{MgO})$. The minerals in COPR are similar to those of COPR used in previous studies. ${ }^{2,17}$ Cellulose with the particle size between 150 and $350 \mu \mathrm{m}$ was purchased from Sigma-Aldrich. The element contents of $\mathrm{C}, \mathrm{H}$, and $\mathrm{O}$ were $42.6 \%, 6.4 \%$, and $50.8 \%$, respectively. The volatile fraction, fixed carbon, and ash of the cellulose are $89.6 \%, 9.7 \%$, and $0.6 \%$, respectively.

Experimental Design. Cellulose Pyrolysis Behavior. The pyrolysis was carried out under a condition filled with $\mathrm{N}_{2}$ (99.99\%) in a fixed-bed tube furnace with an $800 \mathrm{~mm}(\mathrm{~L}) \times 30$ mm (I. D.) quartz tube, shown in Figure S4. For the cellulose pyrolysis, $1 \mathrm{~g}$ of cellulose was put into a $50 \mathrm{~mm} \times 10 \mathrm{~mm}$ porcelain boat and then placed at the remote side of the tube furnace. The quartz tube was first filled with $\mathrm{N}_{2}$ by the flow rate of $20 \mathrm{~mL} \mathrm{~min}{ }^{-1}$. The ceramic boat was then quickly moved to the center of the furnace after the reactor had stabilized at the desired temperature. Fast pyrolysis was conducted and kept for about $10 \mathrm{~min}$ to ensure complete conversion. The pyrolyzed volatiles were then cooled in a sequential ice bath, where the tar was condensed. The noncondensable gases were collected in a gas bag and analyzed by gas chromatography (GC). The char was recovered after it cooled in room temperature under $\mathrm{N}_{2}$ atmosphere. The yields of char, tar, gas and VF from pyrolysis of cellulose were calculated as follows:

$$
\begin{aligned}
& \text { yield }_{\text {char }}=\frac{m_{\text {char }}}{m_{\text {feedstock }}} \times 100 \% \\
& \text { yield }_{\text {tar }}=\frac{m_{\text {tar }}}{m_{\text {feedstock }}} \times 100 \% \\
& \text { yield }_{\text {gas }}=100 \%-\text { yield }_{\text {char }}-\text { yield }_{\text {tar }}
\end{aligned}
$$

$$
\text { yield }_{\text {volatile fraction }}=\text { yield }_{\text {gas }}+\text { yield }_{\text {tar }}
$$

Batch Cr(VI) Reduction Study. The setup of the lab-scale experiment was based on the pilot-scale experiment as introduced in Note 1 of the Supporting Information. The specific cellulose/COPR ratios (Cel/COPR) were achieved by keeping a constant mass of COPR ( $3 \mathrm{~g})$ and varying the mass of cellulose. The mixture was then put into the ceramic boat. After the reactor had stabilized at the desired temperature, the boat was moved quickly to the center of the furnace with the $\mathrm{N}_{2}$ filled with the reactor. The $\mathrm{N}_{2}$ flow was also kept at $20 \mathrm{~mL}$ $\mathrm{min}^{-1}$. At the end, the boat was moved quickly to the cold end of the tube and allowed to cool with the flow of $\mathrm{N}_{2}$. The $\mathrm{Cr}(\mathrm{VI})$ reduction percentage $(\mathrm{CRP})$ was calculated as follow:

$$
\mathrm{CRP}=\frac{C_{0} * M_{0}-C * M}{\mathrm{C}_{0} * M_{0}}
$$

where $C_{0}$ and $C$ are the $\mathrm{Cr}(\mathrm{VI})$ content in COPR before and after pyrolysis, respectively. $M_{0}$ and $M$ are the mass of initial and final COPR. All the experiments were carried out in triplicates, and the results were expressed as means.

Control Cr(VI) Reduction Study. Batch Study. In the study, the main compounds of VF, including tars, chars, gases, formic acid, and formaldehyde, were pyrolyzed with COPR separately. In addition, naphthalene, as a comparatively stable organic, was examined to reduce $\mathrm{Cr}(\mathrm{VI})$. Gases, tars, and chars were produced through the pyrolysis of cellulose at corresponding temperature, respectively. Tars were collected in the ice bath and chars were the solid residues after cellulose pyrolysis. The gas was pyrolyzed with COPR in the following procedure: a preset amount of cellulose was pyrolyzed at a certain temperature in one pyrolyzed reactor (reactor A). The VF generated was first driven by $\mathrm{N}_{2}$ flow $\left(20 \mathrm{~mL} \mathrm{~min}^{-1}\right)$ to the cool system to remove the tar and then to another pyrolyzed reactor (B), where about $3 \mathrm{~g}$ of COPR was laid at a preset temperature. The weights of reductants were varied as shown in Table S3. Tars and chars were pyrolyzed with COPR in the procedure the same as that of batch $\mathrm{Cr}(\mathrm{VI})$ reduction study. The reaction times were all kept as $10 \mathrm{~min}$.

Continuous Study. The furnace was initially heated to preset temperature. The ceramic boat containing $3 \mathrm{~g}$ of COPR was then moved quickly to the center of the furnace under the continuous flow of the reducing gases. The gases, with a flow rate of $40 \mathrm{~mL} \mathrm{~min}^{-1}$, were $\mathrm{H}_{2} / \mathrm{N}_{2}(\mathrm{v} / \mathrm{v}=25: 75), \mathrm{CO} / \mathrm{N}_{2}(\mathrm{v} / \mathrm{v}$ $=25: 75)$, alcohol $/ \mathrm{N}_{2}(\mathrm{v} / \mathrm{v}=25: 75)$, and pentanal $/ \mathrm{N}_{2}(\mathrm{v} / \mathrm{v}=$ 25:75), respectively. After the required reaction time, the boat was moved quickly to the cold end of the tube and allowed to cool with the flow of nitrogen. Alcohol and pentanal gases were produced through vaporization of the two liquids into the $\mathrm{N}_{2}$

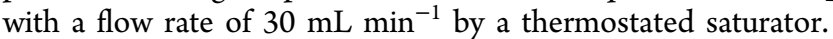

Analytical Methods. The Cr(VI), extracted from 200 mesh of COPR, was measured by an alkaline digestion (United States Environmental Protection Agency, Method 3060a). The gas products were analyzed by a GC with a thermal conductivity detector (20B, Shimadzu). The tar was determined by a gas chromatography-mass spectrometry (5975C, Agilent).

The Cr K-edge X-ray absorption spectra (XAS) study was performed at Beijing Synchrotron Radiation Facility (BSRF), Institute of High-Energy Physics, Chinese Academy of Sciences. Samples were ground to fine powder and packed to a uniform thickness and sealed with transparent adhesive tape. XAS spectra were collected from the samples at beamline $4 \mathrm{~W} 1 \mathrm{~B}$ in a storage ring of $2.2 \mathrm{GeV}$ with an average ring current 
of $90 \mathrm{~mA}$. The spectroscopic data from standard samples, ie $\mathrm{K}_{2} \mathrm{Cr}_{2} \mathrm{O}_{4}$ and $\mathrm{Cr}_{2} \mathrm{O}_{3}$, were collected in transmission mode using pure $\mathrm{N}_{2}$ gas-filled ionization chambers as gas detectors, and the other data were in fluorescence mode. Energy calibration was simultaneously performed for each measurement using a reference $\mathrm{Cr}$ foil placed in front of the third ion chamber and assigning the first inflection point to $5989 \mathrm{eV} . \mathrm{K}_{2} \mathrm{CrO}_{4}$ was used as the references of $\mathrm{Cr}(\mathrm{VI})$, and $\mathrm{Cr}_{2} \mathrm{O}_{3}$ and $\mathrm{CrCl}_{3}$ were both used as the $\mathrm{Cr}(\mathrm{III})$ reference. The EXAFS data were analyzed with the software Winxas 3.1. ${ }^{18}$ The spectra were processed by removing the pre-edge background, normalizing the post-edge, and extracting the EXAFS signals from the spectra. The coordination numbers $(\mathrm{CN})$ and interatomic distances $(\mathrm{R})$ in the $\mathrm{Cr}$ local atomic environment were then determined using EXAFS shell-by-shell fitting.

\section{RESULTS AND DISCUSSION}

Cellulose Pyrolysis Behavior. The distributions of char, tar, and gas during the pyrolysis of cellulose are shown in Figure 1. It was shown that there was a sharp decrease of char

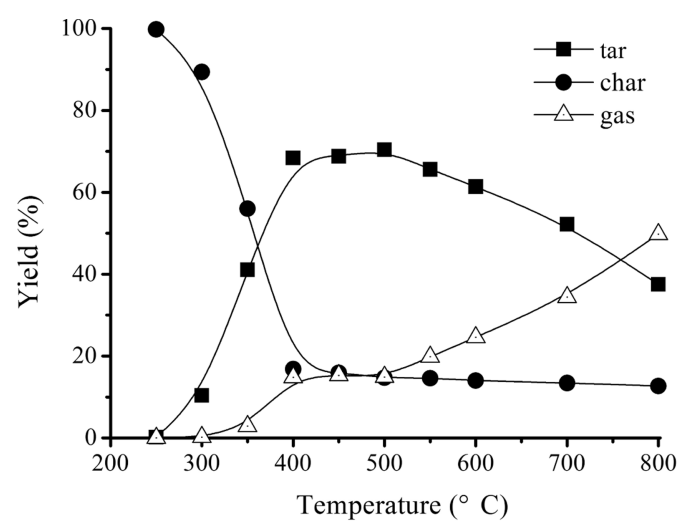

Figure 1. Cellulose pyrolysis behavior and the products distribution.

at pyrolysis temperature from 250 to $400{ }^{\circ} \mathrm{C}$. The tar generated at around $300{ }^{\circ} \mathrm{C}(16.4 \%)$ and reached the maximum (70.4\%) at 400 to $500{ }^{\circ} \mathrm{C}$. The tar occurred a secondary pyrolysis to generate small molecule gases over $500{ }^{\circ} \mathrm{C}$, leading to the increasing of gas. The characteristics of tar at $500{ }^{\circ} \mathrm{C}$ are listed in Table S1. The results showed that the compounds composed of various macromolecular organics, which could be grouped as acids, aldehydes, furans, ketones, etc.

When the temperature was lower than $350{ }^{\circ} \mathrm{C}$, minor gas yielded indicating that the $\mathrm{VF}$ was mainly consisting of macromolecule compounds. The gas yield increased with the increasing of the temperature and reached the maximum of $49.8 \%$ at $800{ }^{\circ} \mathrm{C}$. The incondensable gases from pyrolysis of cellulose were mainly $\mathrm{CO}_{2}, \mathrm{CO}, \mathrm{CH}_{4}, \mathrm{H}_{2}, \mathrm{C}_{2} \mathrm{H}_{4}$, and $\mathrm{C}_{2} \mathrm{H}_{6}$. The portions as a function of temperature, shown in Table S2, indicated that the main compositions were $\mathrm{CO}_{2}(52.6-69.8 \%)$ and $\mathrm{CO}(30.3-36.9 \%)$. The two compounds were mainly caused by the cracking and reforming of $\mathrm{C}=\mathrm{O}$ and $\mathrm{C}-\mathrm{O}-\mathrm{C}^{19}$ The other compounds took off with the increasing of temperature. This tendency was obvious for $\mathrm{H}_{2}$, which was similar to the result from Shi and Wang. ${ }^{20}$ Gas components, such as $\mathrm{CO}, \mathrm{H}_{2}, \mathrm{CH}_{4}, \mathrm{C}_{2} \mathrm{H}_{4}$, and $\mathrm{C}_{2} \mathrm{H}_{6}$, have been proven to have the potential of reducing $\mathrm{Cr}(\mathrm{VI})$ to $\mathrm{Cr}(\mathrm{III})$ in a gas-solid reaction. $^{21,22}$

$\mathrm{Cr}(\mathrm{VI})$ Reduction as a Function of Pyrolysis Variables. The CRP of the COPR at different temperatures is shown in
Figure 2a. It can be seen that the $\mathrm{Cr}(\mathrm{VI})$ reduction was not significant at temperatures below $250{ }^{\circ} \mathrm{C}$. Only $15.5 \%$ of
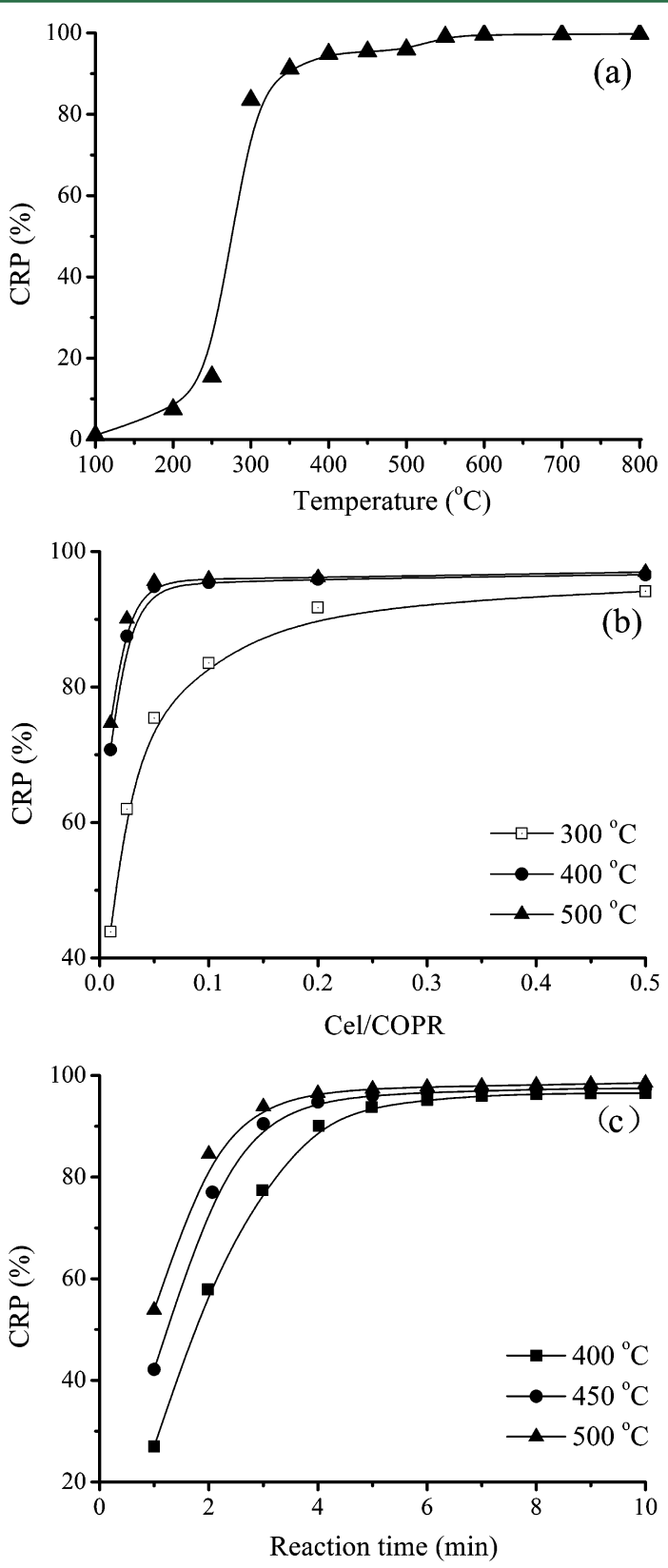

Figure 2. CRP of the COPR as a function of temperature (a), Cel/ COPR (b), and reaction time (c).

$\mathrm{Cr}$ (VI) was reduced at $250{ }^{\circ} \mathrm{C}$, with over $90 \%$ reduction at 400 ${ }^{\circ} \mathrm{C}$. The CRP varied slowly from $94.9 \%$ to $96.0 \%$ with the temperature increasing from 400 to $500{ }^{\circ} \mathrm{C}$. The conversion significantly increased to $99 \%$ at $550{ }^{\circ} \mathrm{C}$. The mixture turned black after pyrolysis (shown in Figure S5) as a result of the carbonaceous residue deposited on the surface of COPR. Carbonaceous residue deposition is a common phenomenon during the pyrolysis of organics. ${ }^{23,24}$ The $\mathrm{pH}$ value of the raw COPR was 12.8 , lower than that of the pyrolyzed one with the $\mathrm{pH}$ value of 12.9 to 13.8 . The increased $\mathrm{pH}$ was probably ascribed to the decomposition of carbonate minerals, such as $\mathrm{CaCO}_{3}$.

Figure $2 \mathrm{~b}$ shows the $\mathrm{Cr}(\mathrm{VI})$ reduction percentage profile with a specific ratio of cellulose and COPR. The increase of 
cellulose caused the CRP increasing until a certain Cel/COPR was attained (for example, 0.2 for $300{ }^{\circ} \mathrm{C}$ and 0.05 for 400 and $500{ }^{\circ} \mathrm{C}$ ). A further increase of $\mathrm{Cel} / \mathrm{COPR}$ had little influence on the $\mathrm{Cr}(\mathrm{VI})$ reduction.

As shown in Figure 2c, the CRP increased sharply at reaction time from 1 to $5 \mathrm{~min}$, following a minor increase. For example, at $500{ }^{\circ} \mathrm{C}$, there was only a slight rise from $97.4 \%$ to $98.5 \%$ with the reaction time of 5 to and $10 \mathrm{~min}$.

XAS Study. XAS study was used to identify the speciation of reduced $\mathrm{Cr}(\mathrm{VI})$. The treated sample was the pyrolyzed COPR at $550{ }^{\circ} \mathrm{C}$ with a Cel/COPR ratio of 0.1 and a reaction time of $10 \mathrm{~min}$. The XANES spectra of the samples are shown in Figure 3. The XANES spectra of treated COPR were similar to

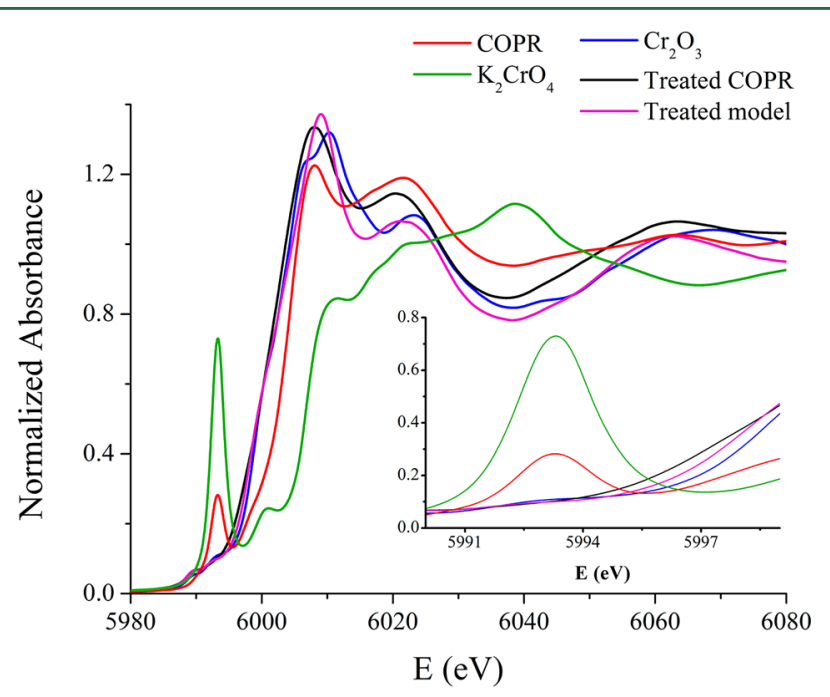

Figure 3. Cr K-edge XAS spectra of the treated and untreated materials CRP.

that of $\mathrm{Cr}_{2} \mathrm{O}_{3}$ at around $5993 \mathrm{eV}$. This indicated that the $\mathrm{Cr}(\mathrm{VI})$ was completely reduced to $\mathrm{Cr}(\mathrm{III})$, which corresponded to the high CRP of over 99\%. However, the XANES result was based on the $\mathrm{Cr}(\mathrm{III})$ reference of $\mathrm{Cr}_{2} \mathrm{O}_{3}$ rather than $\mathrm{CrCl}_{3}$. As shown in Figure S6, the normalized absorbance of $\mathrm{CrCl}_{3}$ was lower than those of $\mathrm{Cr}_{2} \mathrm{O}_{3}$ and treated COPR. Hence, the XANES data alone could not verify the high CRP value. EXAFS was used to further analyze the $\mathrm{Cr}$ speciation. The Fourier transforms of EXAFS spectras for standard $\mathrm{Cr}_{2} \mathrm{O}_{3}$, treated COPR, and the treated model are shown in Figure 4. There

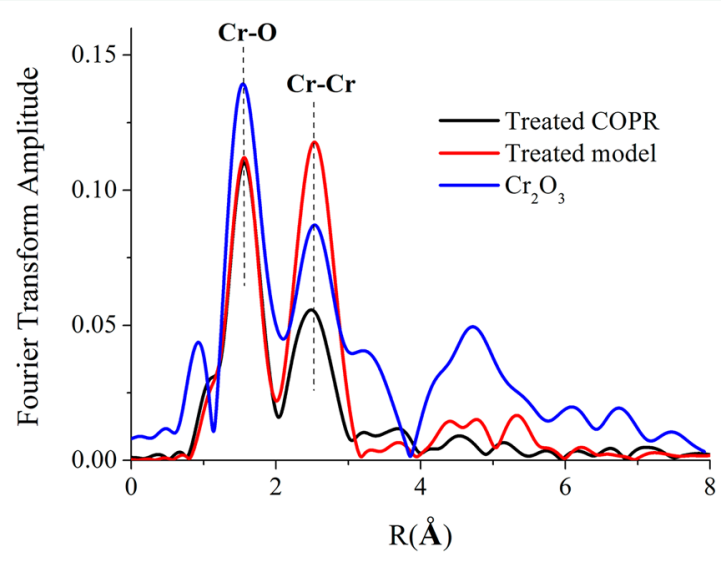

Figure 4. Fourier transforms of EXAFS spectra for the standard $\mathrm{Cr}_{2} \mathrm{O}_{3}$ and the treated model. were two major shells in both materials, the $\mathrm{Cr}-\mathrm{O}$ shell and the $\mathrm{Cr}-\mathrm{Cr}$ shell. Based on the EXAFS spectra, the bond distances and coordination numbers were calculated in Table 1 . It was

Table 1. Fitted Cr K-edge EXAFS Parameters for $\mathrm{Cr}_{2} \mathrm{O}_{3}$ and Treated Model

\begin{tabular}{llrrr}
\multicolumn{1}{c}{ sample } & shell & $\mathrm{CN}^{a}$ & $R(\AA)^{b}$ & $\sigma^{2}\left(\AA^{2}\right)^{c}$ \\
$\mathrm{Cr}_{2} \mathrm{O}_{3}$ & $\mathrm{Cr}-\mathrm{O}$ & 6.0 & 2.00 & 0.004 \\
treated COPR & $\mathrm{Cr}-\mathrm{O}$ & 2.9 & 2.00 & 0.002 \\
& $\mathrm{Cr}-\mathrm{Cr}$ & 3.2 & 2.95 & 0.008 \\
treated Model & $\mathrm{Cr}-\mathrm{O}$ & 3.3 & 2.00 & 0.005 \\
& $\mathrm{Cr}-\mathrm{Cr}$ & 4.9 & 2.97 & 0.007
\end{tabular}

${ }^{a} \mathrm{CN}$ : coordination number. ${ }^{b} \mathrm{R}$ : bond distance. ${ }^{c} \sigma^{2}$ : Debye-Waller factor

shown that $\mathrm{Cr}-\mathrm{O}$ distance and coordination number of standard $\mathrm{Cr}_{2} \mathrm{O}_{3}$ were 2.00 and 6.0, respectively, which was corresponding to the previous research. ${ }^{25}$ The $\mathrm{Cr}-\mathrm{O}$ distance of treated COPR was $2.00 \AA$, in line with that of $\mathrm{Cr}_{2} \mathrm{O}_{3}$. Previous research showed that the bond distances for $\mathrm{Cr}(\mathrm{VI})-$ $\mathrm{O}$ and $\mathrm{Cr}(\mathrm{III})-\mathrm{O}$ were $1.62-1.66 \AA$ and $1.97-2.01 \AA$ respectively. ${ }^{25,26}$ This result further indicated that the $\mathrm{Cr}(\mathrm{VI})$ in COPR was truly reduced to $\mathrm{Cr}(\mathrm{III}) . \mathrm{Cr}_{2} \mathrm{O}_{3}$ was a suitable $\mathrm{Cr}$ (III) reference for XANES detection.

Considering the complicated $\mathrm{Cr}$-containing minerals in COPR, the model COPR was used to better understand the speciation of the reduced $\mathrm{Cr}(\mathrm{VI})$. The model was prepared through calcining the diatomite at $800{ }^{\circ} \mathrm{C}$ to remove the reductants and then spiking $\mathrm{K}_{2} \mathrm{CrO}_{4}$ to the calcined diatomite to produce the model with $\mathrm{Cr}(\mathrm{VI})$ content of $6500 \mathrm{mg} \mathrm{kg}{ }^{-1}$. The model COPR was mixed with the cellulose with Cel/ COPR of 0.1 and then pyrolyzed at $550{ }^{\circ} \mathrm{C}$ for $10 \mathrm{~min}$, which was donated as the treated model. The XANES spectrum of treated model is shown in Figure 3. Its pre-edge peak, around $5993 \mathrm{eV}$, was agreed with that of $\mathrm{Cr}_{2} \mathrm{O}_{3}$. As shown in Table 1 , the $\mathrm{Cr}-\mathrm{O}$ and $\mathrm{Cr}-\mathrm{Cr}$ distances in the treated model were 2.00 and $2.97 \AA$, respectively. Generally, $\mathrm{K}_{2} \mathrm{CrO}_{4}$ should be reduced to $\mathrm{Cr}_{2} \mathrm{O}_{3}$. However, the coordination numbers of $\mathrm{Cr}-\mathrm{O}$ of the treated model was different from that of crystal $\mathrm{Cr}_{2} \mathrm{O}_{3}$. Hence, the reduced $\mathrm{Cr}$ (III) probably was in the form of amorphous $\mathrm{Cr}_{2} \mathrm{O}_{3}$, which was also found in previous study on the reduction of $\mathrm{K}_{2} \mathrm{CrO}_{4}$ by $\mathrm{H}_{2}{ }^{27}$ As mentioned in Note 2 of the Supporting Information, through the thermogravimetric (TG) analysis, it was found that $\mathrm{H}_{2}, \mathrm{CO}$, and $\mathrm{CH}_{4}$ could all reduce the $\mathrm{K}_{2} \mathrm{CrO}_{4}$ into $\mathrm{Cr}_{2} \mathrm{O}_{3}$.

Control Batch $\mathrm{Cr}(\mathrm{VI})$ Reduction. As shown in Table S3, at a lower temperature $\left(500{ }^{\circ} \mathrm{C}\right)$, the $\mathrm{CRP}$ with tar was the highest compared with the results from gas and char. The additions of gas and char facilitated the $\mathrm{Cr}(\mathrm{VI})$ reduction. However, the CRP for char was lower than $10 \%$. The char was in solid state during the pyrolysis and could not fluidized to effectively contact $\mathrm{Cr}(\mathrm{VI})$ in the matrix. At $800{ }^{\circ} \mathrm{C}$, it was shown that gas played a major role in $\mathrm{Cr}(\mathrm{VI})$ reduction. This was ascribed to the increase of gas yield and reduction of tar yield at higher temperature, as shown in Figure 1. Formic acid, formaldehyde, and naphthalene, which could all evaporate at over $500{ }^{\circ} \mathrm{C}$, were found to effectively reduce $\mathrm{Cr}(\mathrm{VI})$. Previous studies also showed that naphthalene and tar could even reduce $\mathrm{Fe}(\mathrm{III})$ to $\mathrm{Fe}(\mathrm{II}) / \mathrm{Fe}(0){ }^{28,29}$ Naphthalene was a relatively inactive reductant with a stable $\mathrm{C}-\mathrm{H}$ bond compared with the alkyl group. Thus, the organics with $\mathrm{C}-\mathrm{H}$ bond from VF could potentially reduce $\mathrm{Cr}(\mathrm{VI})$. It also indicated that derivatives such 
as the carbonyl group and carboxyl group could reduce $\mathrm{Cr}$ (VI) from Table S3. The volatile fraction of cellulose comprised the mentioned three groups. Thus, it could presume that all the organic compounds in the VF as well as $\mathrm{CO}$ and $\mathrm{H}_{2}$ potentially reduced $\mathrm{Cr}(\mathrm{VI})$.

Previous studies showed that $\mathrm{Cr}(\mathrm{VI})$ can be reduced by $\mathrm{CO}$ and $\mathrm{H}_{2}$ in the following way: ${ }^{21,22}$

$$
\begin{aligned}
& \mathrm{CaCrO}_{4}+\mathrm{CO} \rightarrow \mathrm{CaO}+\mathrm{Cr}_{2} \mathrm{O}_{3}+\mathrm{CO}_{2} \\
& \mathrm{CaCrO}_{4}+\mathrm{H}_{2} \rightarrow \mathrm{CaO}+\mathrm{Cr}_{2} \mathrm{O}_{3}+\mathrm{H}_{2} \mathrm{O}
\end{aligned}
$$

The volatile organics, such as hydrocarbon, aromatic, and aliphatic, might reduce $\mathrm{Cr}(\mathrm{VI})$ through direct reduction and indirect reduction. For direct reduction, the $\mathrm{C}-\mathrm{H}$ bonds in the organics could easily react with $\mathrm{Cr}(\mathrm{VI})$ and subsequently reduce it. ${ }^{30,31}$ The carbonyl products were formed after $\mathrm{C}-\mathrm{H}$ bonds reacted with $\mathrm{Cr}(\mathrm{VI}) .^{32,33}$ In the indirect reduction, the secondary cracking of the volatile organics could form new products, which could react with $\mathrm{Cr}(\mathrm{VI})$. For instance, $\mathrm{H}_{2}$ and $\mathrm{CO}$ could form through the dehydrogenation of hydrocarbon $^{33,34}$ and the cracking of carbonyl products, ${ }^{35,36}$ respectively. The $\mathrm{CO}$ and $\mathrm{H}_{2}$ can react with $\mathrm{Cr}(\mathrm{VI})$ as in eqs 6 and 7. The $\mathrm{C}_{2} \mathrm{O}_{3}$, chromite, and calcite in the COPR minerals were all good catalysts for the dehydrogenation and cracking of the macromolecular organics. ${ }^{37}$ Thus, in the ideal condition, the organic compounds could finally be converted to $\mathrm{CO}_{2}$ and $\mathrm{H}_{2} \mathrm{O}$ by $\mathrm{Cr}(\mathrm{VI})$. To better understand the stoichiometric ratio of reducant/oxidant, we proposed MCRA/C. MCRA is the maximum $\mathrm{Cr}(\mathrm{VI})$ reduction amount of the VF in cellulose, and $\mathrm{C}$ is the $\mathrm{Cr}(\mathrm{VI})$ amount in COPR. The calculation of MCRA/C was shown in Note 2 of the Supporting Information. Based on the calculation, the result from Figure $2 \mathrm{~b}$ was converted to the $\mathrm{Cr}(\mathrm{VI})$ reduction as a function of MCRA/C, which was shown in Figure S9.

Figure S8 clearly showed that the $\mathrm{Cr}(\mathrm{VI})$ reduction was highly related with MCRA/C at the three temperatures. The increase of MCRA/C resulted in the CRP increasing until MCRA/C of about 17 was attained. There obviously was adequate volatile reducing compounds for $\mathrm{Cr}(\mathrm{VI})$ reduction. However, even when MCRA/C exceeded 100, the remnant $\mathrm{Cr}(\mathrm{VI})$ content in the pyrolyzed products was still high $(>100$ $\mathrm{mg} / \mathrm{kg}$ ). The reason will be explained in the next section.

Control Continuous $\mathrm{Cr}(\mathrm{VI})$ Reduction. Figure S9 introduced the VF generation as a function of reaction time. The figure showed there was also a sharp increase of VF generation at reaction time from 1 to $5 \mathrm{~min}$, followed a minor increase. For example, the VF increased only from $74.7 \%$ to $85.3 \%$ with the reaction time from 5 to $10 \mathrm{~min}$ at $500{ }^{\circ} \mathrm{C}$. The VF shortage probably caused the slight rise of CRP at the reaction time from 5 to $10 \mathrm{~min}$.

To better understand the $\mathrm{Cr}(\mathrm{VI})$ reduction behavior, we studied the continuous $\mathrm{Cr}(\mathrm{VI})$ reduction with the flows of $\mathrm{H}_{2}$, $\mathrm{CO}$, alcohol, and pentanal. As shown in Figure 5, the CRP decreased along with the increase of reaction time. For all of the reducing gases, the final $\mathrm{Cr}(\mathrm{VI})$ contents at $10 \mathrm{~min}$ were below $22 \mathrm{mg} \mathrm{kg}{ }^{-1}$, lower than that from batch $\mathrm{Cr}(\mathrm{VI})$ study. It confirmed that remnant $\mathrm{Cr}(\mathrm{VI})$ could be further reduced when continuously contacted with reducing gas. From Figure $5, \mathrm{H}_{2}$ performed the highest reduction rate with the final $\mathrm{Cr}(\mathrm{VI})$ content of $3.1 \pm 0.5 \mathrm{mg} \mathrm{kg}^{-1}$, and the final $\mathrm{Cr}(\mathrm{VI})$ content of copyrolyzed with pypentanal was $20 \pm 1.5 \mathrm{mg} \mathrm{kg}$. It was obviously seen that gas products $\left(\mathrm{H}_{2}\right.$ and $\left.\mathrm{CO}\right)$ performed better than the tar products (alcohol and pentanal). With light
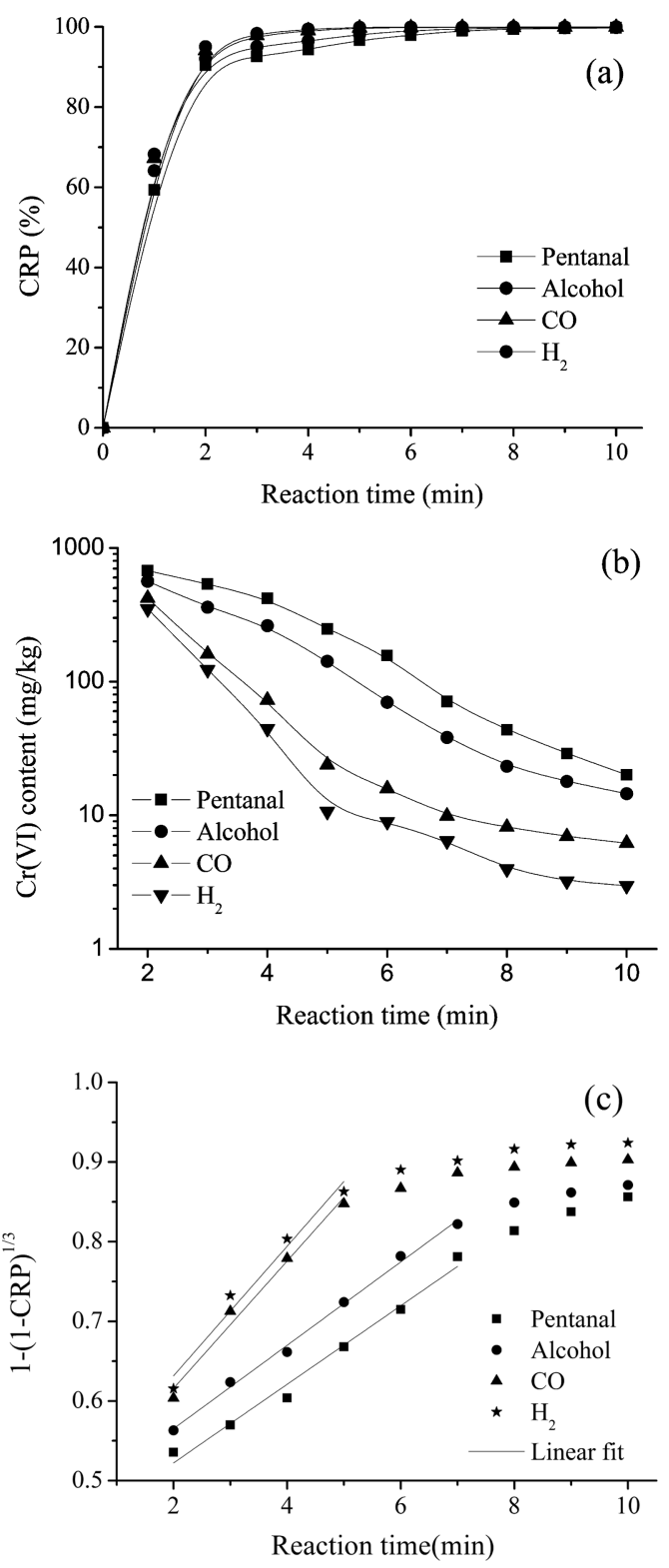

Figure 5. Isothermal $\mathrm{Cr}(\mathrm{VI})$ reduction under various reducing gas ((a): CRP, (b): Cr(VI) content, and (c): model stimulation).

molecules, low kinetic diameters (or collision diameters), and viscosity, the gas products easily penetrated the matrix of COPR and reduced $\mathrm{Cr}(\mathrm{VI}) .^{29,38,39}$

A 3D phase-boundary model $\left(1-(1-\mathrm{CRP})^{1 / 3}=K t\right)^{39}$ was used to stimulate the $\mathrm{Cr}(\mathrm{VI})$ reductiom kinetics. The initial $2 \mathrm{~min}$ reaction time was excluded due to the impact of heating process on the $\mathrm{Cr}(\mathrm{VI})$ reduction. From Figure $5 \mathrm{c}$, it was found there were linear relationships between $1-(1-C R P)^{1 / 3}$ and reaction time in the initial stage with CRP below 99\%. The trend gradually became flat in the later stage due to the probable domination of intraparticle diffusion. Previous results showed that the reductions of $\mathrm{Fe}_{2} \mathrm{O}_{3}$ to $\mathrm{Fe}(\mathrm{II}) / \mathrm{Fe}(0)$ by $\mathrm{H}_{2}$ and $\mathrm{CO}$ were initially controlled by phase boundary reaction and followed by intraparticle diffusion. ${ }^{29,40,41}$ It required over 30 min to achieve $90 \%$ conversion of Fe (III) to $\mathrm{Fe}$ (II)/Fe (0), and it required less than $10 \mathrm{~min}$ to achieve an over $99 \%$ conversion of $\mathrm{Cr}(\mathrm{VI})$ to $\mathrm{Cr}(\mathrm{III})$. Generally, $\mathrm{Cr}(\mathrm{VI})$ was distributed on the surface and diffuse in the COPR due to the fact that $\mathrm{Cr}(\mathrm{VI})$ was physically and chemically adsorbed by 
the minerals of COPR during the lixiviation of water to recover $\mathrm{Cr}(\mathrm{VI}) .^{12,42}$

As shown in Figure $6 a$, the particle size of COPR was reduced to below 200 mesh to achieve a better performance.
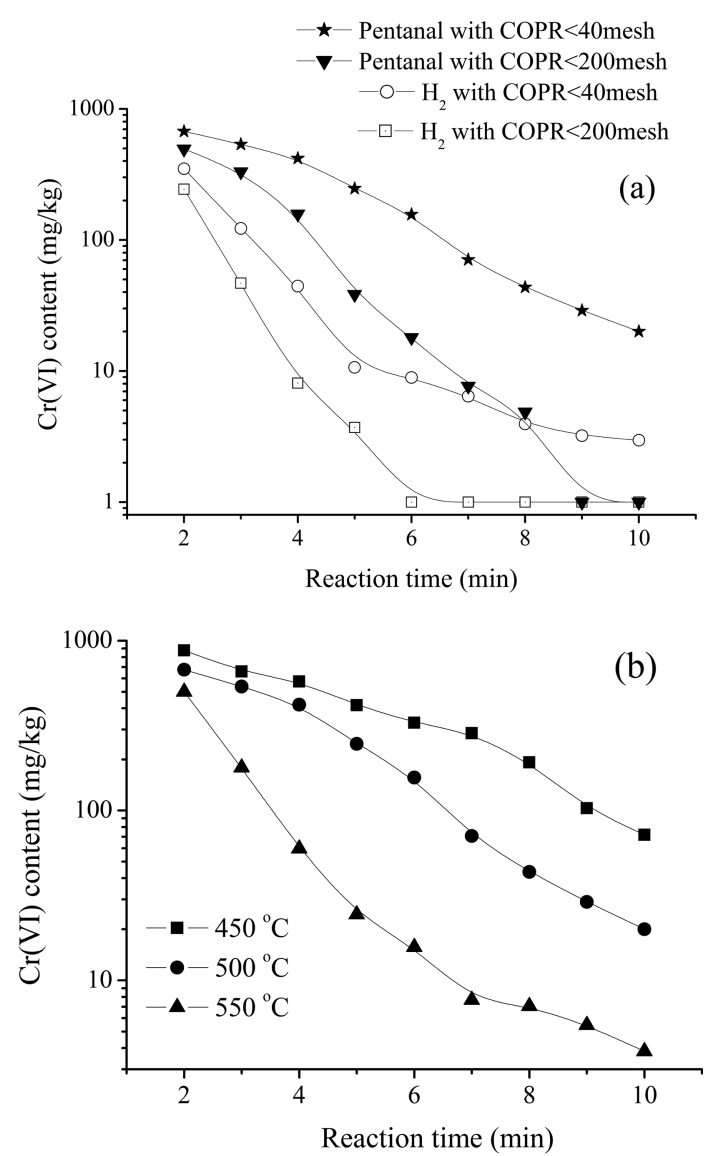

Figure 6. Isothermal $\mathrm{Cr}(\mathrm{VI})$ reduction as a function of particle size (a) and temperature $(\mathrm{b})(\mathrm{Cr}(\mathrm{VI})$ content below detection limit was assigned to be $1 \mathrm{mg} / \mathrm{kg}$ ).

Under the continuous flow of $\mathrm{H}_{2}$, the $\mathrm{Cr}(\mathrm{VI})$ was below the detection limit $(2 \mathrm{mg} / \mathrm{kg})$ after $4 \mathrm{~min}$. It required $9 \mathrm{~min}$ to achieve the same content for pentanal. Figure $6 \mathrm{~b}$ shows the isothermal $\mathrm{Cr}(\mathrm{VI})$ reduction as a function of temperature. It indicated that high temperature obviously helped the $\mathrm{Cr}(\mathrm{VI})$ reduction for higher temperature and could help $\mathrm{Cr}(\mathrm{VI})$ reduction in the generation of low-molecule-reducing gases, as shown in Figure 1.

Environmental Significance. Effective reaction time between $\mathrm{VF}$ and $\mathrm{Cr}(\mathrm{VI})$ was important for $\mathrm{Cr}(\mathrm{VI})$ reduction during the pyrolysis. However, in the present pilot-scale pyrolysis system, as shown in Figure S2, the inert hot gas, generated from the incomplete combustion of fuel (excess air ratio: 0.95), can take away the VF generated from biomass pyrolysis. Hence, it could reduce the effective reaction time between $\mathrm{VF}$ and $\mathrm{Cr}(\mathrm{VI})$. It seemed rational to generate $\mathrm{VF}$ from cellulose-containing biomass in one pyrolysis reactor initially. The VF was then flown to internal heat rotary kiln where COPR motioned in a reverse direction to achieve a longer effective contact time between VF and COPR. The temperature in the reactor for biomass pyrolysis could be higher to generate more reducing gas for a better $\mathrm{Cr}(\mathrm{VI})$ reduction performance. Other available organic wastes, such as plastics and sewage sludge, can also be used as reductants because they may generate the volatile organics as well as $\mathrm{CO}$ and $\mathrm{H}_{2}$ during pyrolysis.

It was verified in this study that $\mathrm{Cr}_{2} \mathrm{O}_{3}$ was a suitable $\mathrm{Cr}$ (III) standard reference through the XANES coupled with EXAFS method. However, $\mathrm{Cr}_{2} \mathrm{O}_{3}$ had a higher absorbance value at $5993 \mathrm{eV}$ than other standard $\mathrm{Cr}(\mathrm{III})$ references such as $\mathrm{CrCl}_{3}$ or $\mathrm{Cr}\left(\mathrm{NO}_{3}\right)_{3}$, which were usually used as standard $\mathrm{Cr}(\mathrm{III})$ reference in many previous reported researches on $\mathrm{Cr}(\mathrm{VI})$ detection by XANES alone method. ${ }^{2,14,43,44}$ Hence, EXAFS study was required to be performed on the rationality of the $\mathrm{Cr}(\mathrm{III})$ standard sample in these studies.

\section{ASSOCIATED CONTENT}

\section{Supporting Information}

The Supporting Information is available free of charge on the ACS Publications website at DOI: 10.1021/acs.est.5b05707.

Additional details on Polit scale experiment of the pyrolysis treatment of COPR, thermogravimetric of $\mathrm{Cr}(\mathrm{VI})$ reduction under the reducing gases, and calculation of MCRA/C. Tables showing components identification of tars obtained at $500{ }^{\circ} \mathrm{C}$, gas compositions as a function of temperature, batch control $\mathrm{Cr}$ (VI) reduction study, elemental contents of organic fractions in the char, and calculated element contents of volatile fraction from the cellulose and its corresponding maximum $\mathrm{Cr}(\mathrm{VI})$ reduction capacity. Figure showing the pilot-scale experiment equipment, a schematic diagramt of the pilot-scale experiment apparatus, XRD pattern of Chinese COPR, schematic diagram of apparatus for pyrolysis, images of mixture of COPR plus cellulose before and after pyrolysis, Cr K-edge XAS spectra of the treated and untreated materials, TG study of $\mathrm{K} 2 \mathrm{CrO} 4$ in the different reducing gas, $\mathrm{Cr}(\mathrm{VI})$ reduction as a function of MCRA/C, and VF yield as a function of reaction time. (PDF)

\section{AUTHOR INFORMATION}

\section{Corresponding Authors}

*Tel and fax: +86 532 85071255; e-mail: zdl8288@163.com.

*Tel and fax: +86 532 80662750; e-mail: yuanxz@qibebt.ac.cn.

Notes

The authors declare no competing financial interest.

\section{ACKNOWLEDGMENTS}

This research was supported by financial aid from National Natural Science Foundation of China (No. 51008164), Natural Science Foundation of Shandong Province (ZR2014EEM041) and China Postdoctoral Science Foundation (2014M561889).

\section{REFERENCES}

(1) Kanchinadham, S. B. K.; Loganathan, V. D.; Kalyanaraman, C. A preliminary study on leachability of chromium from a contaminated site. Environ. Prog. Sustainable Energy 2013, 32 (4), 1096-1100.

(2) Dermatas, D.; Moon, D. H.; Chrysochoou, M.; Grubb, D. G.; Wazne, M.; Christodoulatos, C. Ettringite-Induced heave in chromite ore processing residue (COPR) upon ferrous sulfate treatment. Environ. Sci. Technol. 2006, 40, 5786-5792.

(3) Földi, C.; Dohrmann, R.; Mansfeldt, T.; Matern, K. Characterization of chromium-containing wastes and soils affected by the production of chromium tanning agents. J. Soils Sediments 2013, 13 (7), 1170-1179. 
(4) Brose, D. A.; James, B. R. Hexavalent chromium reduction in solution and in chromite ore processing residue-enriched soil by tartaric acid with isopropyl alcohol and divalent manganese as coreductants. J. Environ. Qual. 2013, 42 (3), 766-773.

(5) Bewley, R. J. F.; Jeffries, R.; Watson, S.; Granger, D. An overview of chromium contamination issues in the south-east of Glasgow and potential for remediation. Environ. Geochem. Health 2001, 23, 267271.

(6) Meegoda, J. N. Remediation of chromium-contaminated soils: Bench-scale investigation. Practice Periodical of Hazardous, Toxic, and Radioactive Waste Management 1999, 3 (3), 124-131.

(7) Tokunaga, T. K.; Wan, J.; Lanzirotti, A.; Sutton, S.; Newville, M.; Rao, W. Long-term stability of organic carbon-stimulated chromate reduction in contaminated soils and its relation to manganese redox status. Environ. Sci. Technol. 2007, 41 (12), 4326-4331.

(8) Kožuh, N.; Štupar, J.; Gorenc, B. Reduction and oxidation processes of chromium in soils. Environ. Sci. Technol. 2000, 34 (1), 112-119.

(9) Sun, T.; Chen, J.; Lei, X.; Zhou, C. Detoxification and immobilization of chromite ore processing residue with metakaolinbased geopolymer. J. Environ. Chem. Eng. 2014, 2 (1), 304-309.

(10) Du, J.; Lu, J.; Wu, Q.; Jing, C. Reduction and immobilization of chromate in chromite ore processing residue with nanoscale zerovalent iron. J. Hazard. Mater. 2012, 215-216, 152-158.

(11) Hillier, S.; Lumsdon, D. G.; Brydson, R.; Paterson, E. Hydrogarnet: A host phase for $\mathrm{Cr}(\mathrm{VI})$ in chromite ore processing residue (COPR) and other high $\mathrm{pH}$ wastes. Environ. Sci. Technol. 2007, 41 (6), 1921-1927.

(12) Chrysochoou, M.; Fakra, S. C.; Marcus, M. A.; Moon, D. H.; Dermatas, D. Microstructural analyses of $\mathrm{Cr}(\mathrm{VI})$ speciation in chromite ore processing residue (COPR). Environ. Sci. Technol. 2009, 43 (14), 5461-5466.

(13) He, Y. T.; Chen, C. C.; Traina, S. J. Inhibited Cr(VI) reduction by aqueous $\mathrm{Fe}(\mathrm{II})$ under hyperalkaline conditions. Environ. Sci. Technol. 2004, 38 (21), 5535-5539.

(14) Moon, D. H.; Wazne, M.; Jagupilla, S. C.; Christodoulatos, C.; Kim, M. G.; Koutsospyros, A. Particle size and $\mathrm{pH}$ effects on remediation of chromite ore processing residue using calcium polysulfide (CaS5). Sci. Total Environ. 2008, 399 (1-3), 2-10.

(15) Zhang, D.; He, S.; Kong, H.; Dai, L.; Hu, X.; Wu, D.; Peng, K.; $\mathrm{Bu}$, G.; Pang, H. Treatment of Chromite Ore Processing Residue by pyrolysis with rice straw. Chemosphere 2009, 77 (8), 1143-1145.

(16) Zhang, D.; He, S.; Kong, H.; Dai, L.; Xie, Y.; Wu, D.; Bu, G.; Peng, K. Impact of pyrolysis process on the chromium behavior of COPR. J. Hazard. Mater. 2009, 172 (2-3), 1597-1601.

(17) Kamolpornwijit, W.; Meegoda, J. N.; Hu, Z. Characterization of chromite ore processing residue. Pract. Period. Hazard., Toxic, Radioact. Waste Manage. 2007, 11 (4), 234-239.

(18) Ressler, T. WinXAS: A program for X-ray absorption spectroscopy data analysis under MS-Windows. J. Synchrotron Radiat. 1998, 5 (2), 118-122.

(19) Patwardhan, P. R.; Dalluge, D. L.; Shanks, B. H.; Brown, R. C. Distinguishing primary and secondary reactions of cellulose pyrolysis. Bioresour. Technol. 2011, 102 (8), 5265-5269.

(20) Shi, X.; Wang, J. A comparative investigation into the formation behaviors of char, liquids and gases during pyrolysis of pinewood and lignocellulosic components. Bioresour. Technol. 2014, 170, 262-269.

(21) Jóźwiak, W. K.; Ignaczak, W.; Dominiak, D.; Maniecki, T. P. Thermal stability of bulk and silica supported chromium trioxide. Appl. Catal., A 2004, 258 (1), 33-45.

(22) Lillehaug, S.; Jensen, V. R.; Børve, K. J. Catalytic dehydrogenation of ethane over mononuclear $\mathrm{Cr}(\mathrm{III})$-silica surface sites. Part 2: C - H activation by oxidative addition. J. Phys. Org. Chem. 2006, 19 (1), $25-33$.

(23) Airaksinen, S. M. K.; Bañares, M. A.; Krause, A. O. I. In situ characterisation of carbon-containing species formed on chromia/ alumina during propane dehydrogenation. J. Catal. 2005, 230 (2), 507-513.
(24) Korhonen, S. T.; Airaksinen, S. M. K.; Krause, A. O. I. In situ characterization of carbonaceous deposits formed on chromia/zirconia during isobutane dehydrogenation. Catal. Today 2006, 112 (1-4), $37-39$.

(25) Park, D.; Yun, Y. S.; Park, J. M. XAS and XPS studies on chromium-binding groups of biomaterial during $\mathrm{Cr}(\mathrm{VI})$ biosorption. $J$. Colloid Interface Sci. 2008, 317 (1), 54-61.

(26) Wang, S. L.; Lee, J. F. Reaction mechanism of hexavalent chromium with cellulose. Chem. Eng. J. 2011, 174 (1), 289-295.

(27) Li, P.; Xu, H. B.; Zheng, S. L.; Zhang, Y.; Li, Z.-H.; Bai, Y.-L. A green process to prepare chromic oxide green pigment. Environ. Sci. Technol. 2008, 42 (19), 7231-7235.

(28) Ma, C.; Luo, S. Y.; Bu, Q. J. Coupling of degration of tar model compound naphthalene with direct reduction of iron ore for ironmaking (In Chinese). Renewable Energy Resource. 2015, 33 (7), 1097-1102.

(29) Luo, S.; Yi, C.; Zhou, Y. Direct reduction of mixed biomass$\mathrm{Fe} 2 \mathrm{O} 3$ briquettes using biomass-generated syngas. Renewable Energy 2011, 36 (12), 3332-3336.

(30) Botavina, M. A.; Martra, G.; Agafonov, Y. A.; Gaidai, N. A.; Nekrasov, N. V.; Trushin, D. V.; Coluccia, S.; Lapidus, A. L. Oxidative dehydrogenation of $\mathrm{C} 3-\mathrm{C} 4$ paraffins in the presence of $\mathrm{CO} 2$ over $\mathrm{CrOx} / \mathrm{SiO} 2$ catalysts. Appl. Catal., A 2008, 347 (2), 126-132.

(31) Botavina, M. A.; Evangelisti, C.; Agafonov, Y. A.; Gaidai, N. A.; Panziera, N.; Lapidus, A. L.; Martra, G. CrOx/SiO2 catalysts prepared by metal vapour synthesis: Physical-chemical characterisation and functional testing in oxidative dehydrogenation of propane. Chem. Eng. J. 2011, 166 (3), 1132-1138.

(32) Lau, T. C.; Wu, Z. B.; Bai, Z. L.; Mak, C.-K. Dalton communications. Lewis-acid catalysed oxidation of alkanes by chromate and permanganate. J. Chem. Soc., Dalton Trans. 1995, 4, 695-696.

(33) Carotenuto, G.; Tesser, R.; Di Serio, M.; Santacesaria, E. Kinetic study of ethanol dehydrogenation to ethyl acetate promoted by a copper/copper-chromite based catalyst. Catal. Today 2013, 203, 202210.

(34) Weckhuysen, B. M.; Schoonheydt, R. A. Alkane dehydrogenation over supported chromium oxide catalysts. Catal. Today 1999, 51 (2), 223-232.

(35) Lv, G.; Wu, S.; Yang, G.; Chen, J.; Liu, Y.; Kong, F. Comparative study of pyrolysis behaviors of corn stalk and its three components. J. Anal. Appl. Pyrolysis 2013, 104, 185-193.

(36) Neri, G.; Pistone, A.; De Rossi, S.; Rombi, E.; Milone, C.; Galvagno, S. Ca-doped chromium oxide catalysts supported on alumina for the oxidative dehydrogenation of isobutane. Appl. Catal., A 2004, 260 (1), 75-86.

(37) Arena, U.; Di Gregorio, F. Energy generation by air gasification of two industrial plastic wastes in a pilot scale fluidized bed reactor. Energy 2014, 68, 735-743.

(38) Li, J. R.; Kuppler, R. J.; Zhou, H. C. Selective gas adsorption and separation in metal-organic frameworks. Chem. Soc. Rev. 2009, 38 (5), $1477-1504$

(39) Luo, M.; Wang, S.; Wang, L.; Lv, M. Reduction kinetics of ironbased oxygen carriers using methane for chemical-looping combustion. J. Power Sources 2014, 270, 434-440.

(40) Kazemi, M.; Glaser, B.; Sichen, D. Study on direct reduction of hematite pellets using a new TG setup. Steel Res. Int. 2014, 85 (4), $718-728$.

(41) Tiernan, M. J.; Barnes, P. A.; Parkes, G. M. B. Reduction of iron oxide catalysts: The investigation of kinetic parameters using rate perturbation and linear heating thermoanalytical techniques. J. Phys. Chem. B 2001, 105 (1), 220-228.

(42) Tinjum, J. M.; Benson, C. H.; Edil, T. B. Treatment of Cr(VI) in COPR using ferrous sulfate-sulfuric acid or cationic polysulfides. $J$ Geotech. Geoenviron. Eng. 2008, 134 (12), 1791-1803.

(43) Malherbe, J.; Isaure, M. P.; Séby, F.; Watson, R. P.; RodriguezGonzalez, P.; Stutzman, P. E.; Davis, C. W.; Maurizio, C.; Unceta, N.; Sieber, J. R.; Long, S. T.; Donard, O. F. X. Evaluation of hexavalent chromium extraction method EPA method 3060A for soils using 
XANES spectroscopy. Environ. Sci. Technol. 2011, 45 (24), 1049210500.

(44) Moon, D. H.; Wazne, M.; Koutsospyros, A.; Christodoulatos, C.; Gevgilili, H.; Malik, M.; Kalyon, D. M. Evaluation of the treatment of chromite ore processing residue by ferrous sulfate and asphalt. $J$. Hazard. Mater. 2009, 166 (1), 27-32. 